\title{
A CRITICAL LEGAL ANALYSIS ON THE MINIMUM AGE OF CRIMINAL RESPONSIBILITY IN THE NEW ISLAMIC PUNISHMENT ACT OF IRAN
}

\section{Shohreh Mousavi, ${ }^{1}$ Jal Zabdi Mohd Yusoff, Farah Nini Dusuki and Behnam Rastegari}

\begin{abstract}
The provision for a minimum age of criminal responsibility (MACR) is stated in a number of international children's rights instruments. The preamble of the United Nations Convention on the Rights of the Child (UNCRC) states that a child, by reason of his physical, mental and emotional immaturity is in need of special safeguards, care and assistance. Despite remarkable improvements in a number of provisions, an examination of the Iran's laws and regulations reveal that the provision of MACR is currently in conflict with the international instruments particularly the UNCRC. This is despite the fact that Iran is a State Party of the UNCRC since. Furthermore, the Iranian Civil Code expressly provide that the government is to implement the UNCRC provisions as an international treaty. This article critically examines the position of the MACR and punishments of children in the new Islamic Punishment Act of Iran (2013) based on the four Islamic categories of punishments namely Hadd, Qisas, Diya and Ta'zir as enshrined in the new Act. The current article places emphasis on the examination of the issue of MACR in Iran and how effectively it is addressed by the new Act. The nature of this research is doctrinal by examining the new Act of Iran 2013 with a critical legal overview on the Articles relating to children and their impact on the rights of children. Furthermore, it compares the relevant Articles on MACR and punishments of the new Act with the previous abolished Act and the international standards. The purpose is to highlight both the limitations and advancements of the new Act. In the final analysis, this article concludes that despite the improvements in the field of children's rights in the new Act, it still poses potential risks for the rights of the children in Iran.
\end{abstract}

PhD Candidate at Faculty of Law, University of Malaya, 50603 Kuala Lumpur, Malaysia. 
Keywords: Children's rights, minimum age of criminal responsibility, convention on the rights of the child, punishment, new Islamic Punishment Act of Iran, legal analysis.

\section{Introduction}

The interplay between children and crime has always been a contentious issue; for whilst no one like to think of a child as a perpetrator of crime neither can we tolerate nor fully understand the factors contributing to the formation of delinquency among youth. Historically, children were generally treated more punitively than reformatively, depending on their position within the structure of society and the family in the particular culture. Discipline and maltreatment for the sake of correcting astray children were, and are being commonly imposed. Whippings, floggings, spankings and other forms of physical punishment have been among the common ways of disciplining troubled children. Over time, it has been shown and proven by numerous research that juvenile delinquents, one ought to treat a juvenile as a person and should try to penetrate into the juvenile's mind rather than keeping them behind cold walls. For a juvenile who committed a crime at a very tender age, the time spent in a cell will eventually impact his/her behaviour later in the future and treating him like a criminal will stigmatise him indefinitely. It must be noted that the child is entitled to basic guarantees afforded to adults as well as legal or other assistance for his or her defence. Judicial proceedings and institutional placements shall be avoided wherever possible. ${ }^{2}$

It has been accepted that the legal and penal systems for children ought to be separate and different from adults. At the international level, all international children's rights instruments contain protective and supportive aspects for children, for example, the Beijing Rules in Rule 4 (1) states that the beginning of the age of criminal responsibility shall not be fixed at too low an age level, bearing in mind the facts of emotional, mental and intellectual maturity. In addition the Beijing Rules in Rule 2(2) (a) provides a

\footnotetext{
2 Nayagam, James,"Strengths and Weaknesses of the Protection Mechanism and Support System for Reintegration of Children in Conflict with Law. Human Rights and the Administration of Juvenile Justice “, (2009) Suhakam's Conference in Conjunction with Malaysian Human Rights, at 50.
} 
juvenile is a child or young person who, under, the respective legal systems, may be dealt with for an offence in a manner which is different from an adult. ${ }^{3}$ The juvenile death penalty is prohibited by international law, and the prohibition is absolute, as both the $\mathrm{UNCRC}^{4}$ and International Covenant on Civil and Political Rights (ICCPR $)^{5}$ specifically prohibit capital punishment for persons under the age of 18 at the time of the offence. Islamic Republic of Iran ratified the ICCPR in 1975 and the UNCRC in 1994 and accordingly are obliged to observe the UNCRC provisions, however, despite its improvements, it has failed to do so concerning the MACR.

The criterion of maturity for the acts of children is a potentially risky factor in criminal cases and could be considered to be against the principle of "the best interest of the child", provided by Article $3^{6}$ and also Article $1^{7}$ of the UNCRC. For instance within Article 91 of the new Islamic Punishment Act of Iran in Hadd or Qisas punishments the capacity of the offenders under the age of 18 depends on the maturity through the recognition of the court. Article 91 states:

"In the cases of offenses punishable by Hadd or Qisas, if mature people under eighteen years do not realize the nature of the crime committed or its prohibition, or if

3 Abiad, Nisrine and Farkhanda Zia Mansoor, Criminal Law and the Rights of the Chid in Muslim State: A Comparative and Analytical Perspective, (London: British Institute of International and Comparative Law, 2010), at 24.

4 United Nations Convention on the Rights of the Child (UNCRC), adopted and opened for signature, ratification and accession by General Assembly resolution 44/25 of 20 November 1989 entry into force 2 September 1990.

5 International Covenant on Civil and Political Rights (ICCPR), adopted December 16, 1966, G.A. Res. 2200A (XXI), 21 U.N.GAOR Supp. (No. 16) at 52, U.N. Doc. A/6316 (1966), 999 U.N.T.S. 171, entered into force March 23, 1976.

6 Article 3 of the UNCRC states: "1. In all actions concerning children, whether undertaken by public or private social welfare institutions, courts of law, administrative authorities or legislative bodies, the best interests of the child shall be a primary consideration. 2 . States Parties undertake to ensure the child such protection and care as is necessary for his or her well-being, taking into account the rights and duties of his or her parents, legal guardians, or other individuals legally responsible for him or her, and, to this end, shall take all appropriate legislative and administrative measures. 3. States Parties shall ensure that the institutions, services and facilities responsible for the care or protection of children shall conform with the standards established by competent authorities, particularly in the areas of safety, health, in the number and suitability of their staff, as well as competent supervision".

For the purposes of the present Convention, a child means every human being below the age of eighteen years. 
there is uncertainty about their full mental development, according to their age, they shall be sentenced to the punishments prescribed in this chapter. Note: The court may ask the opinion of forensic medicine or resort to any other method that it sees appropriate in order to establish the full mental development".

Therefore, as the maturity is neither a fixed nor a statutorily guided concept, but totally discretionary it could be violating the rights of the child, particularly the right to life in Hadd or Qisas punishments in Iran.

Article 146 of the new Islamic Punishment Act states: "Nonmature children have no criminal responsibility". In Iran, the end of puberty is upon the start of adulthood and the beginning of criminal responsibility. The end of puberty is defined in Iranian Laws as 14 years seven months (15 lunar years) for boys and eight years and nine months (nine lunar years) for girls, according to the Article 147 of the new Islamic Punishment Act: "The age of maturity for girls and boys are, respectively a full nine and fifteen lunar years". The state of the different ages of puberty for male and female children is seen to be arbitrary and discriminatory that is clearly violates the principle of non-discrimination (Article 2) of the UNCRC.

Based on what age is applied by jurisdictions, the legislations regarding to the rights and duties of children are different. For instance, in many other jurisdictions, children may ride a motorcycle at the age of 16 whilst they can only obtain the license to drive at the age of 17 . Girls below 16 and boy below 17 who wish to marry may only do so with the special permission of the courts. According to the written law, a child's capacity to act depend not so much on age, but maturity, so there is no simple way adults can really be sure of what adolescents may lawfully do. ${ }^{8}$

This research explores the differences and progress of the new Act of Iran (2013) compared with abolished Islamic Punishment Act of Iran in the provisions related to children's rights specially the MACR. In

\footnotetext{
8 Dusuki, Farah Nini, Protection of Children's Rights, Human Rights Law: International, Malaysian and Islamic Perspectives In Abdul Ghafur Hamid@ Khin Maun Sein, Thomson Reuters Malaysia, 2012), at 197.
} 
addition, it considers the legal perspective and the situation of the MACR and sentencing in the new Islamic Punishment Act of Iran.

\section{Minimum Age of Criminal Responsibility on the Repealed Islamic Punishment Act of Iran}

Under the Repealed Islamic Punishment Act, criminal responsibility is typically assigned to individuals based upon the respective age of puberty of the offender (Article 49 and Note 1 of the Article 49). Abolished Islamic Punishment Act of Iran exempts minors from criminal responsibility if found guilty of committing an offence, as stated in Article 49 of the abolished Act of Iran, allowing for the responsibility to be assumed by the guardians of the child or by detaining the child in a centre for juvenile correction (Article 49). The protection offered to a child in relation to criminal responsibility, however, is limited only to children who have not reached the age of puberty under Islamic jurisprudence through Note 1 of the Article 1210 Civil Code. The age of puberty is, in turn, determined by Article 1210(1) of the Civil Code, which defines the end of childhood as the age of puberty. The age of puberty was generally accepted to be 15 lunar years (14 years and seven months) of age for males and nine lunar years (eight years and nine months) of age for females which still is same. Therefore, the definition of the age of puberty in the Civil Code has been used by the previous Islamic Punishment Act to determine the age of criminal responsibility for boys and girls. Thus, if a girl older than nine years or a boy over 15 years of age commits a crime, they are adjudicated as adults.

\section{Minimum Age of Criminal Responsibility in the New Islamic Punishment Act of Iran}

The Islamic Consultative Assembly (Parliament) decided to eliminate, amend and add explicit provisions of punishment for children, in response to the criticisms of the previous abolished Islamic Punishment Act by the international community and Iranian lawyers. For example, the new Act has often postponed the execution of the death penalty for juvenile convicts until they reach the age of 18 which will be referenced below in more detail. However; a similar trend is obvious in the latest amendments to the abolished Islamic Punishment Act. The new Act has signed by the President 
and then published in the Official Gazette. As the trial period of the previous Islamic Punishment Act expired in 2008, the Bill on the Islamic Punishment Act was submitted to the Parliament in 2008 by the Judiciary through the government. The ratification process of the new Islamic Punishment Act was finally finished in March 2012 after its endorsement/approval Guardians Council. It is still before the Legal and Judicial Commission of the Parliament is (as per Article 85 of the Constitution) for consideration, it is not yet formally into force. ${ }^{9}$ It came into effect on June 2013, and officially replaced with the previous Islamic Punishment Act in 2013. Based on the Third Periodic Report on the Convention on the Rights of the Child: the Islamic Republic of Iran's changes (in provisions of the new Act) related to the children, seems to be rooted in international force and criticisms. The new Act supersedes the previous Act, which followed the religious majority criterion. ${ }^{10}$

In Chapter Ten (Punishment and Security and Correctional Measures for Children and Young People) of Part 2 (Punishments) of the new Act Articles 88 to 95 generally address punishments and correctional measures applied to "children and adolescents." Unlike the previous Act, the new Act defines the "age of criminal responsibility" for the first time, but pegs it to the age of puberty under Shari'ah law (Article 147). Accordingly, judges may not hold girls under nine lunar years and boys under 15 lunar years criminally responsible for their actions or omissions (Article 146). This was already the practice under the previous Act, but the new Act includes a specific provision codifying the age requirement. ${ }^{11}$

According to Article 146 of the new Act "any human being under the age of puberty are exempt from criminal responsibility". At the first sight and with a comparison between two Acts, there is a separate provision for the lack of definition of the age of puberty. Vice versa, the previous Act, definition of the age of puberty (Known as Boloogh) has been explicitly stated in Article 147 of the new Act (15 lunar years for boys and nine lunar years for girls). While, Articles

The Third Periodic Report on the Convention on the Rights of the Child: The Islamic Republic of Iran (2013), at 11-81.

10 Ibid.

11 Sanei, Faraz, Codifying Repression: An Assessment of Iran's New Penal Code, (New York: Human Rights Watch, 2012), at 22. 
146 and 147 of the new Act similar to the previous Act continues to set the age of religious puberty as the MACR. Therefore, the MACR is based on the age of religious puberty, because Article 146 of the new Act exempts immature children from criminal responsibility. According to Article 147 of the new Act, criminal responsibility is gradually applied between the ages of nine (eight years and nine months) lunar years for girls and 15 (14 years and seven months) lunar years of age for boys.

Therefore, the discrimination between the attribution of criminal responsibility for girls and boys still exist. In addition, contrary to the previous Act, the New Act has stipulated the age of puberty. Thus, a reference to the Civil Code for definition of the age of puberty is not required. However, expectations for the MACR to be raised by the new Islamic Punishment Act have not materialized ${ }^{12}$ because Articles 146 and 147 of the new Act create no change from the previous Act. In addition, there are a number of contradictions on criminal responsibility between the provisions of the new Act. For instance Article 146 exempts minors from criminal responsibility yet on the other hand Article 148 provides correctional and security measures for immature offenders, as Article 148 states: "In the cases of non-mature children, security and correctional measures shall be applied in accordance with the provisions of this law". The issue here is how Article 146 exempts immature children from criminal responsibility while Article 148 stipulates of the compensating for the crime of an immature person?

\section{Punishments in the New Islamic Punishment Act of Iran}

According to Article 14 of the new Act, punishments provided in this law are divided into four categories including Hudud, Qisas, Diyat, Ta'zirat. Hadd (plural: Hadd. Literally, 'boundary or limit') is a punishment for which the grounds for, type, amount and conditions of execution are specified in holy Shari'ah (Article 15 of the new

12 Nayyeri, Mohammad H, "Criminal Responsibility of Children in the Islamic Republic of Iran's New Penal Code”, (2010) Iran Human Rights Documentation Center. http:// www.iranhrdc.org/english/publications/legal-commentary/1000000054-criminalresponsibility-of-children-in-the-islamic-republic-of-irans-new-penal-code.html 
Islamic Punishment Act). Qisas (literally, 'retaliation') is defined as a punishment 'equivalent to the crime, which God has prescribed for Jinayat (intentional murder or bodily harm) (Article 16 of the new Islamic Punishment Act). Qisas is the main punishment for intentional bodily crimes against life, limbs, and abilities which shall be applied. Diya is financial compensation or blood money against the person committed the crime, Diya, whether fixed or unfixed, is a monetary amount under holy Shari' $a$, which is determined by law and shall be paid for unintentional bodily crimes against life, limbs and abilities or for intentional crimes when for whatever reason causes is not applicable (Article 17 of the new Islamic Punishment Act). Ta'zir (plural: Ta'zir. Literally 'chastisement') is defined as punishment imposed for an act which are not specified in Shari'ah and are left to "the discretion of the Islamic judge. According to Article 18 of the new Islamic Punishment Act, "Ta' zir is a punishment which does not fall under the categories of Hadd, Qisas, or Diya and is determined by law for commission of prohibited acts under Shari'ah or violation of state rules. The type, amount, conditions of execution as well as mitigation, suspension, cancellation and other relevant rules of Ta'zir crimes shall be determined by law. In making decisions in Ta'zir crimes, while complying with legal rules, the court shall consider the following issues:

(a) The offender's motivation and his/her mental and psychological conditions when committed the crime

(b) Method of committing the crime, extent of a breach of duty and its harmful consequences

(c) Conduct of the offender after committing the crime

(d) The offender's personal, family, and social background and the effect of the Ta'zir punishment on him/her".

\section{Criminal Responsibility and the Special Correctional and Security Measures}

Criminal responsibility and the special correctional and security measures of children are considered as important issues within the new Act. Seven Articles of the New Act from Article 88 to 95 have addressed the issues of criminal responsibility and the special correctional and security measures applicable to children. In this section, persons defined as children are divided into four categories 
according to Hadd; Qisas and Ta'zir punishments, moreover the MACR and gender are important when Hadd or Qisas punishments are subjects.

\section{i) Ta'zir crimes: children under the age of 9 years}

When children below the age of 9 years old commit Ta'zir crimes, there will be no criminal responsibility under the law neither will there be any correctional and security measures regardless whether the person is a girl or boy. They are completely immune from prosecution as the result of the new Act.

\section{ii) Ta'zir crimes: children between the ages of 9 and 15 years}

When children between the ages of 9 to 15 years commit Ta'zir crimes, the court shall sentence this group of children to minor correctional and security measures such as submission to their parents with the promise of correction, sending the child to a social worker or psychologist or banning them from visiting specific persons or places (Article 88). However, in the case of serious Ta'zir crimes which are committed by children between the ages of 12 to 15 years, the court may sentence the child to be held in a correction and rehabilitation center from three months to one year (Note 1 of Article 88). There is no difference between girl and boy in this category of crimes. In this respect, Article 88 states:

The court shall make one of the following decisions, whichever is more appropriate, about the children and young people who have committed Ta'zir offenses whose age at the time of commission is between nine to fifteen years according to the solar calendar:

Note 1: Decisions mentioned in paragraphs (d) and (e) shall only be applied on a child or youth between 12 and 15 years. In the case of commission of Ta'zir crimes of the first to fifth degree, application of the provisions of paragraph (e) shall be mandatory.

(d) Cautioning and warning or taking a written promise not to commit an offense again 
(e) Detention in the Correction and Rehabilitation Center from three months to one year in the case of Ta'zir offenses of the first to fifth degree.

According to Article 88 to 95 of the new Act, three categories of ages can be considered for the child offenders. First, offenders under the ages of 9 years old; second the offenders between the ages of 9 and 15 years old; and the third adolescent offenders between the ages of 15 and 18 years old.

\section{iii) T'azir crimes: children between the ages of 15 and 18 years}

Children between the ages of 15 to 18 years who commit Ta'zir crimes, their sentences will be based on the severity of the crime. In the case of serious Tazi'r crimes, the sentence is limited to a maximum of five years in a correctional and rehabilitation center. For the less serious degree of Ta'zir crimes, the sentence will not exceed more than 2 years in a correctional and rehabilitation center, public service and financial fines. This category is same for girl and boy (Article 89). Article 89 of the new Islamic Punishment Act states:

The following punishments shall be given to young people who commit Ta'zir crimes and they are between fifteen to eighteen years of age at the time of commission of the crime:

(a) Detention in Correctional and Rehabilitation Center from two to five years in the case of offenses punishable by law, by a Ta'zir punishment of the first to third degree.

(b) Detention in Correctional and Rehabilitation Center from one to three years in the case of offenses punishable by law, by a Ta'zir punishment of the fourth degree.

(c) Detention in Correctional and Rehabilitation Center from three months to one year or a fine of ten million $(10,000,000)$ Rials to forty million $(40,000,000)$ Rials or providing one 
hundred and eighty to seven hundred and twenty hours of unpaid public services in the case of offenses punishable by law by a Ta'zir punishment of the fifth degree.

(d) A fine of one million $(1,000,000)$ Rials to ten million $(10,000,000)$ Rials or providing sixty to one hundred and eighty hours of unpaid public services in the case of offenses punishable by law by a Ta'zir punishment of the sixth degree.

(e) A fine of up to one million $(1,000,000)$ Rials in the case of offenses punishable by law, by a Ta'zir punishment of the seventh and eighth degree.

Note 1: Hours of providing public services shall not exceed four hours a day.

Note 2: Considering the accused person's condition and the crime committed, the court, at its discretion, instead of sentencing him/her to detention or a fine prescribed in paragraphs (a) to (c) of this article, can order the offender to stay at home in specific hours determined by the court or detention in the Correction and Rehabilitation Center in the weekend for three months to five years".

\section{iv) The new Islamic Punishment Act: death penalty abolished for discretionary crimes}

A noteworthy area of improvement in the new Act caters for children who commit "discretionary crimes"13. Under the new amendments,

13 "Discretionary crimes" include drug trafficking and possession, Article 87 of the new code provides that children who are between the ages of nine and 15 when they commit "discretionary crimes" or ta'zir crimes may be subject to a series of minor correctional and rehabilitation measures, including strict supervision by parents or other legal guardians, referral to social workers, limitations on their freedom of movement, or transfer to a correctional facility between three months to one year. Article 88 provides harsher penalties for children who are between 15 to 18 years when they commit a "discretionary crime," including monetary fines and transfer to a correctional facility up to five years (depending on the severity of the "discretionary crime"). Indeed, the new code does not seem to apply "age of maturity" requirements to ta'zir crimes at all. 
children who commit discretionary crimes are no longer subject to execution. Judges are instead required to sentence such child offenders found guilty of "discretionary crimes" to a variety of corrections and rehabilitation measures depending on the nature of their crime and age range including drug trafficking, which carry heavy punishments under Iran's Anti-Narcotics Law. Article 88 of the new Act provides for situations where children who are between the ages of nine and fifteen commit "discretionary crimes" or Ta'zir crimes. They may be subject to a series of minor corrections and rehabilitation measures, including strict supervision by parents or other legal guardians, referral to social workers, limitations on their freedom of movement, or transfer to a correctional facility between three months to one year. Article 89 provides harsher penalties for children who are between 15 to 18 years when they commit a "discretionary crime". The penalties include monetary fines and transfer to a correctional facility for up to five years (depending on the severity of the discretionary crime). The new Act appears not apply "age of maturity" requirements to Ta'zir crimes at all. This is a somewhat positive step given that the vast majority of all the executions carried out by authorities over the past few years have involved drug trafficking crimes which are considered "discretionary crimes". ${ }^{14}$

\section{v) Hadd or Qisas crimes: children under the age of 9 years}

A child who has not reached the MACR (age of puberty) and commit Hadd or Qisas crimes shall be subject to minor corrections and security measures such as submission to his parents with the promise of correction; sending the child to a social worker or psychologist; or banning him from visiting specific persons or places, according to the Note 2 of the Article 88. It means, if the child offender is a girl under the MACR (age of puberty: 8 years and 9 months (lunar years), she shall be treated the same and also if the child offender is a boy who has not reached the MACR (age of puberty: 14 years and 7 months (lunar years) he shall be treated the same as above mentioned.

$14 \quad$ Sanei, Faraz, Codifying Repression: An Assessment of Iran's New Penal Code, at 22. 
Note 2 of the Article 88 of the new Islamic Punishment Act stipulates:

If a child who has not become mature commits any of offenses punishable by Hadd or Qisas, if child is from 12 to 15 years of age, child shall be sentenced to one of the measures provided in paragraphs (d) or (e); otherwise, one of the measures provided in paragraphs (a) to (c) of this Aticle shall be applicable. Article 88 (a), (b) and (c): "(a) Handing over to parents or natural or legal guardians while taking promises to correct and educate the child or youth and taking care of their good behavior; (b) Handing over to other natural or legal persons that the court finds to be in the best interest of the child or youth by ordering the measures mentioned in paragraph (a) where, considering article 1173 of the Civil Code, the parents or natural or legal guardians of the child or youth or not competent or available; (c) Advising [the child or youth] by the judge.

This is in relation to boys before the age of 15 and girls before the age of 9 years, according to 147 that defines the age of puberty. Thus, when a girl who has reached the age of puberty but is under 9 years old (8 years and 10 months (lunar years), she may be subject to Hadd or Qisas punishments. Unless, based on Article 91, she does not understand the nature of the committed crime or its prohibition, or if there is a doubt about their mental development and perfection, then, according to their age, they shall be awarded one of the punishments provided in this chapter. To recognize the mental development and perfection, the court may ask for the opinion of forensic medicine or employ other means which it deems appropriate.

\section{vi) Hadd or Qisas crimes: children between the age of 9 and 15 years}

In this case of age (between the age of 9 and 15 years), gender of the child is important because it forms the basis for the MACR. When the child offender is a boy and he has not reached the age of puberty however, he is between the age of 9 and 12 years, according to article 88 , he shall be subject to minor correctional and security measures (Note 2 of the Article 88). In this category also the MACR 
is a significant issue, when a boy who has not reached the MACR (14 years and 7 months (lunar years) but he is between the ages of 12 to 15 years who committed Hadd or Qisas crimes, same severe Ta 'zirat crimes he may be convicted to up to one year in Correctional and Rehabilitation Center (Note 2 of the Article 88). However, in respect to the girls and for the reason that girl in this category of age has reached the age of puberty, on the other hand she may be subject to Hadd or Qisas punishments. In addition, if children have reached the age of puberty for boys 15 lunar years, they may be subject to Hadd or Qisas punishments.

\section{vii) Hadd or Qisas crimes: children between the age of 15 and 18 years}

In this category of age (between the age of 15 and 18 years), boys and girls have reached to the age of puberty and they have criminal responsibility. In fact, based on Article 90, children under the age of 18 who have committed Hadd or Qisas crimes will be sentenced to Hadd or Qisas punishments, unless forensic medicine or the judge can prove that they do not have the mental capacity to understand the nature or prohibition of their actions. If a child understands the nature of the crime and confirm his/her mental development by the forensic medicine or judge (Note of Article 91), Hadd or Qisas punishments for children under the age of 18 years old have not been abolished and it is still possible for child and juvenile offenders to be sentenced to Hadd or Qisas punishments.

Article 91 of the new Act states: "In the cases of offenses punishable by Hadd or Qisas, if mature people under eighteen years do not realize the nature of the crime committed or its prohibition, or if there is uncertainty about their full mental development, according to their age, they shall be sentenced to the punishments prescribed in this chapter. The accompanying Note states that the court may ask the opinion of forensic medicine or resort to any other method that it sees appropriate in order to establish the full mental development".

Thus, when a boy after the age of 15 lunar years (14 years and 7 months) and a girl after the age of 9 years ( 8 years and 9 months) committed Hadd or Qisas crimes and at the time of committing they cannot prove their mentally mature and develop, and cannot 
recognize and appreciate the nature and consequences of their actions, they will be subjected to Hadd or Qisas rules. Note of the Article 91 provides in recognizing the mental development and perfection, the court may ask for the opinion of forensic medicine or employ other means which it deems appropriate. On the other hand, children after the age of puberty who are convicted of Hadd or Qisas crimes can be exempted from sentences if the child has not understood the nature of the crime that the court may ask the opinion of forensic medicine or resort to any other method that it sees appropriate in order to establish the full mental development.

This Article gives judges the discretion to decide whether a child has understood the nature of the crime and therefore whether he/ she can be sentenced to death and will be treated as adults or not. The arbitrary nature, such as this may violate the rights of the child, if the judge leans towards a more punitive than protective stance towards the child. As repeatedly stated by various international and regional instruments, children like adults, have right to liberty and freedom and the right to life even upon the commission of crimes. As, between 2007 and 2009, the UN General Assembly (UNGA) twice specifically called upon Iran to end the juvenile death penalty, and the Member States again raised their concerns regarding this issue during Iran's Universal Periodic Review in February 2010. ${ }^{15}$

\section{The New Act: A Critical Legal Analysis}

As a general analysis, it is certainly undeniable that the new Act has made certain improvements as compared to the repealed Act. This is particularly so on the abolishment of juvenile executions for children below the age of 18 years who do not realize the nature of the crime committed or its prohibition, or if there is uncertainty about their full mental development. The new Act pays cognizance to the criteria of "mental development" and "gradual criminal liability" to establish the criminal liability of the children. The absolute criminal age has also increased to 18 years old.

According to the new Act, there have been some desirable changes in respect to Ta'zir punishments. As a result, if children commit

15 Sanei, Faraz, Codifying Repression: An Assessment of Iran's New Penal Code, at 20. 
Ta'zir crimes under the age of 18 years, whether they are boys or girls, and whether they have reached the age of puberty or not, they shall only be subject to correction and security measures. Thus, there is no possibility for application of adult Ta'zir punishments on children and juveniles. In comparison, under the previous Act there was the possibility for application of adult Ta'zir punishments for children and juveniles who have reached the age of MACR (age of puberty). These changes are regarded as positive, especially for girls. In addition, the possibility of averting Hadd or Qisas in a situation which lack of mental development has been proven to be another positive change, though this is arguable and it does not completely solve the problem. ${ }^{16}$

In the new Act, there is a possibility of the application of Hadd or Qisas punishments on children under the age of 18 years, since the new Act, neither abolishes the death penalty for adolescents who cannot prove their mental inability to committing the crime, nor formally raises the MACR. The MACR is particularly important in the penalties for serious crimes, such as Qisas or Hadd. Due to this reason, in international legal systems, the death penalty and life imprisonment have been prohibited for children if crimes committed before they reached the age of 18, including those sentenced to Qisas for murder or to death for Hadd crimes that carry the death penalty. In this respect, Article 37 of the UNCRC provides neither capital punishment nor life imprisonment without possibility of release shall be imposed for offences committed by persons below 18 years of age.

The changes and reforms of the legal perspective in Iran regarding the MACR, though commendable, unfortunately remain in conflict with certain contemporary trends in the international development of children's rights. There are also many important issues of children's rights which should be discussed in the new Act as the factor of the age of puberty for determination of the MACR; the difference of the MACR with physical, intellectual and social realities; the difference of the MACR between girls and boys; the lack of intellectual maturity in definition of the MACR; the difference between the exemption of criminal responsibility for minors in Article 145 of the

\footnotetext{
Nayyeri, Mohammad H, "Criminal Responsibility of Children in the Islamic Republic of
} Iran's New Penal Code". 
new Act with Article 148, that prescribes punishment for minors; and the low and different of the MACR in Iran with provisions of international instruments particularly the UNCRC.

\section{Conclusion and Recommendations}

Despite positive improvements of the new Act of Iran in comparison with the strict abolished Act in the field of children's rights, especially in the case of child executions, there remains a grave concern with respect to the fulfillment of the best interests of children. Certain aspects such as the prevalence of absolute prohibition of the death penalty for the child offenders under the age of 18 clearly contradicts Article 37 of the UNCRC which prohibits any form of degrading or death penalty for children. Iran as a State Party of the UNCRC is legally responsible to comply with such provision, since, Iran signed the UNCRC in September of 1991 and ratified the UNCRC in July of 1994, but reserving the right to not apply any provision of the UNCRC that is not compatible with Islamic Laws and the international legislation in effect. ${ }^{17}$ According to the Committee on the Rights of the Child (CRC) in their Concluding Observations, the UNCRC is binding and has the force of law in Iran in accordance with Articles 77 of the Constitution and 9 of the Civil Code of Iran. ${ }^{18}$

Based on the demographic profile of 47 per cent of Iran's population being under the age of 18 , the legislators must change their attitude from a more punitive stance to a protective approach in line with the international standards in cases affecting children. Lastly regrettably, there remains the existing trend of discrimination between boys and girls in respect to certain provisions which goes against the basic and fundamental principle of non-discrimination of the UNCRC. Although relatively new and fresh from its enactment date, it is unfortunate that the time has come for a serious review of the new Act so that children will not be subjected to adverse treatment by the law which go against their basic needs and rights of existence. In this respect, the CRC committee expressed remains concerns with the existing poor quality of the rules and practices in the juvenile

\footnotetext{
17 Convention on the Rights of the Child, Ratifications and Reservations, Office of the United Nations High Commissioner for Human Rights, available at: http://www.ohchr. org/english/ countries/ratification/11.htm.

18 Committee on the Rights of the Child, Concluding Observations of the Committee on the Rights of the Child: Iran, CRC/C/15/Add.123 (Jun. 28, 2002).
} 
justice system, reflected, inter alia, in the lack of statistical data, the limited use of specialized juvenile courts and judges, the low age of criminal responsibility, the lack of adequate alternatives to custodial sentences, and the imposition of torture and other cruel or inhuman punishment and in particular of the death penalty. ${ }^{19}$ The most serious problems with the new Act include the following:

(a) retention of the death penalty for child offenders;

(b) retention of previously discriminatory provision of the MACR against girls. $^{20}$

As recommended by the CRC, the State Party should review its legislation so that the definition of the child and minimum age requirements conform to the principles and provisions of the Convention, Articles 2 (right to non-discrimination); 3 (best interests of the child); 6 (right to life, survival and development); and 12 (respect for the views and feelings of the young child) and in particular that they are gender neutral, and ensure that they are enforced. ${ }^{21}$ The current Article recommends that Iran:

(a) Review its legislation on the MACR, since the legal age of criminal responsibility is one of the problems that needs to be resolved by Iranian religious jurists and lay lawyers, as it is in other legal systems as well and the fixing of the boundaries of criminal responsibility and the necessary attention to maturity age without any discrimination ${ }^{22}$;

(b) Immediately abolish the death penalty in Iran's law for child offenders;

(c) Reconsider the existing Articles of the MACR with a view to rising the MACR and eliminating existing

19 Committee on the Rights of the Child, Thirty-eighth session, Consideration of Reports Submitted by States Parties under Article 44 of the Convention, Concluding observations: The Islamic Republic of Iran, CRC/C/15/Add.254, 31 March 2005).

20 Sanei, Faraz, (2012) Codifying Repression: An Assessment of Iran's New Penal Code, at 11.

21 Committee on the Rights of the Child, Twenty-Fourth Session, Consideration of Reports Submitted by States Parties under Article 44 of the Convention, Concluding observations of the Committee on the Rights of the Child, Islamic Republic of Iran, CRC/C/15/ Add.123, 28 June 2000.

22 Committee on the Rights of the Child Consideration of Reports Submitted by States Parties under Article 44 of the Convention, Second Periodic Reports of States Parties Due in 2001, Islamic Republic of Iran, CRC/C/104/Add.3, 1 December 2003. 
(d) discrimination of the MACR between girls and boys; and

(e) Vigorously pursue enforcement of international standard age of the child, according to the UNCRC in the new Islamic Punishment Act of Iran.

\section{References}

Abiad, Nisrine and Farkhanda, Zia Mansoor. (2010). Criminal Law and the Rights of the Chid in Muslim State: A Comparative and Analytical Perspective. London: British Institute of International and Comparative Law.

Dusuki, Farah Nini. (2012). Protection of Children's Rights, Human Rights Law: International, Malaysian and Islamic Perspectives. In Abdul Ghafur Hamid @ Khin Maun Sein. Thomson Reuters Malaysia.

International Covenant on Civil and Political Rights (ICCPR), adopted December 16, 1966, G.A. Res. 2200A (XXI), 21 U.N.GAOR Supp. (No. 16) at 52, U.N. Doc. A/6316 (1966), 999 U.N.T.S. 171, entered into force March 23, 1976.

Nayagam, James. (2009). Strengths and Weaknesses of the Protection Mechanism and Support System for Reintegration of Children in Conflict with Law. Human Rights and the Administration of Juvenile Justice (Suhakam's Conference in Conjunction with Malaysian Human Rights).

Nayyeri, Mohammad H. (2012). Criminal Responsibility of Children in the Islamic Republic of Iran's New Penal Code. Iran Human Rights Documentation Center.

Office of the United Nations High Commissioner for Human Rights. Convention on the Rights of the Child, Ratifications and Reservations, http://www.ohchr.org/english/ countries/ ratification/11.htm

Office of the United Nations High Commissioner for Human Rights. United Nations Convention on the Rights of the 
Child (UNCRC), http://www.ohchr.org/en/professionalinterest pages/crc.aspx

Sanei, Faraz, (2012) Codifying Repression: An Assessment of Iran's New Penal Code, New York: Human Rights Watch,http://www.iranhrdc.org/english/publications/ legal-commentary/1000000054-criminal-responsibility-ofchildren-in-the-islamic-republic-of-irans-new-penal-code. html

UN Committee on the Rights of the Child. Concluding Observations of the Committee on the Rights of the Child: Iran, CRC/C/15/ Add.123 (Jun. 28, 2002).

UN Committee on the Rights of the Child (CRC), UN Committee on the Rights of the Child: Concluding Observations: The Islamic Republic of Iran, 31 March 2005, CRC/C/15/ Add.254, available at: http://www.refworld.org/ docid/43f305350.html 31 March 2005).

UN Committee on the Rights of the Child, Twenty-Fourth Session. Consideration of Reports Submitted by States Parties under Article 44 of the Convention, Concluding observations of the Committee on the Rights of the Child, Islamic Republic of Iran, CRC/C/15/Add.123, 28 June 2000.

UN Committee on the Rights of the Child. Consideration of Reports Submitted by States Parties under Article 44 of the Convention, Second Periodic Reports of States Parties Due in 2001, Islamic Republic of Iran, CRC/C/104/Add.3, 1 December 2003.

The Third Periodic Report on the Convention on the Rights of the Child: The Islamic Republic of Iran. (2013). 